\title{
Is Your Child at Risk?
}

\author{
Romina Ghassemi* \\ Founder, Inventor \& Posture Specialist, BAX-U posture support, USA
}

Submission: September 27, 2018; Published: November 13, 2018

*Corresponding author: Romina Ghassemi, Founder, Inventor \& Posture Specialist, BAX-U posture support, USA

Keywords: Posture problems, Back pain, Cavities, Whispering, Giggling, Slouching, Beautifully, Slender

\section{Opinion}

Posture problems in youth is rising right under your nose. Are you a parent reading this article? Do you suffer from neck or back pain after a long day at work? Headaches maybe? Did you wake up with pain? Maybe you didn't, but the other $65 \%$ of working population did, dose and do go thru their days in discomfort. You don't stop eating because you are afraid of cavities? Then why do you expect the millennial to give up their smart devices? How many children do you see already in poor state of health? How many do you know personally? Just like cavities, using smart devices puts us at risk. It's not about "What is wrong?" it's about how are were reacting to it individually? What is the compelling reason to make a change before becoming the victim of the consequences?

\section{Let me share a personal story}

It was a hot summer day, their laughter echoed like angles singing, Tina, Melisa and Helen, the 14 year old splashing around the pool as the parents Barbecued and talked sports. Tom was watching his Tina, with a smile of joy, with his cousins. As a doctor her knew the long hours was rewarded by watching his family joyful. The girls stood outside the pool, whispering and giggling, he noticed Tina is standing a bit crooked, and is really slouching compared to his cousins. It caught his eye, the smile change slowing to an objective analysis. He watched Tina walk to grab towels from the other side of the garden when he knew something is off, she IS crooked. What happened? He calls his wife, Fay, a protective Jewish Mom, who despite work, social life, and community involvement monitored her children like mother bear. He turns to her with fearful concern, "What is going on with Tina?" she proudly replies, "I know she is growing up so beautifully, she reminds me of my self at her age, tall and slender." as she flaunts her hair with a smile. he looks at her, "what the hell are you talking about, look at her pelvis, her back, it's not right!"

Fay, wide eyed looks at her, then at him." "Tina, sweetheart come here, come here!" Uninterestedly and dutifully, she walks over with her head and neck forward, long wavy hair covering her slender thin body, and rounded shoulders. Fay watches her daughter's hips, posture, and remembers how she is more introverted with others, how her baby is all crooked in her bikini. This can't be happening, Fay a doctor herself, immediately dose a posture analysis, "Stand up straight" she checks her Head, ears, shoulder blades, Back, Pelvis, Hip, Knees. "Turn around honey". John stands there and looks at her daughter and wife, a unsettling feeling of concern wraps around his stomach. Tina's head is 6" over her shoulders. Her right scapula is notably rotated back, and her right pelvis is 3 " higher than the left side. "Mom, are you done. Girls are waiting for me?" Fay and John look at each other in concern, Fay, eagerly says; "Honey we'll make an appointment with Romina she is her god-daughter. She will take care of her".

I greet my best friend Fay and Tina, (as smiled and thought, love these girls, last time they visited my Clinic was when she was 4 years old. Then she fell of the kitchen counter). They usually see the local Chiropractor, only urgent matters start with me. I know there is a problem! We walk to the exam room. Fay shares her concern about Tina's posture and how in past year she has been laying on her beanie bag, creating movies, playing games and doing her homework on her laptop. She has been complaining of neck and back pain, with frequent headaches, that Tylenol helps. "We have been telling her to standup straight, and she slouches" maybe she listens to you. Last week at BBQ party we noticed that her pelvis is off, can you check her?"

I proceed with my examination, which was obvious for Forward head position (phase II) and pelvis unleveling, postural distortion. X-rays, will determine if her posture problems are skeletal or muscular, and to what ratio of physiological involvement of muscles to bone effect. I sat in my office, looking at Tina's X-rays, shocked! Tears pour down, how do I share this with Fay? From the mirror window in my office I can see them giggling over her nail polish. My voice is muted holding back the tears as I draw lines, angles, and measurements on her X-rays, wiping off the unstoppable tears. 
OMG, OMG, why did this happen? This is my baby girl! This is my god daughter.

I put myself together as I wear my white coat, maybe the coat can give me strength. I pull myself together, pull my hair back, clear my throat, stand up, and force a smile. I call them to the consultation room, prior to showing the X-rays I start my explanation. "Recently within the past few years there has been a notable rise in number of young adolescents and adults suffering from neck, upper back and lower back pains." In past we blamed heavy back packs, now we have an added insult to the growing fragile bodies of our children. The side effects of smart devices integration in children's lives. In fact; Kaiser family research states "An average 8-18 year old spends about 7.5hrs a day on some form of smart device."

You see, there are 3 common factors that contribute to poor posture are:
a) Muscular problem
b) Structural problem
c) Functional problem

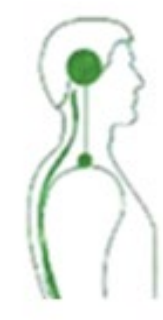

A.

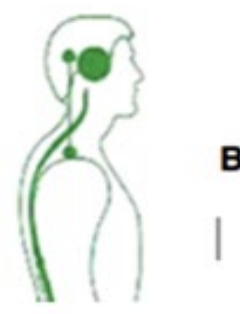

B.

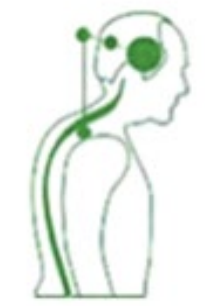

c.

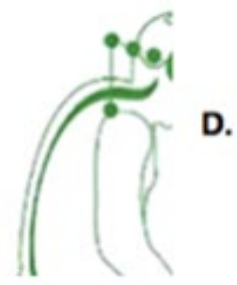

Figure 1

- Muscular Problems are poor muscle balance, usually due to developed bad habits. Such as beanie bags, text neck, playing games on hand held devices. In adults it could be poor ergonomics at work or when driving. Usually most noticed with stiffness, and muscle aches (Figure 1).

- $\quad$ Structural problems are deeper issues. Specifically speaking is changes to the skeletal system. This generically is known as "Scoliosis". An X-ray can identify the source being born with (congenital) or if it is developed later in life (structural).

- $\quad$ Functional Problems are when the skeletal system and the muscular systems changes to the point that the joints have lost their integrity and are not moving in correct aligned synchronicity. This will lead to early wear and tears at joint lets and create bones spurs, fusions and early arthritis. (Reported cases of bone spurs in teenagers are becoming a health concern.)

I show Tina what normal X-ray looks like from front and from side. Explaining the importance of correct alignment. I open the view to reveal her X-rays. Fay gasps, tears weld in her eyes, as she knows what this means. Tina's jaw drops, in a nervous joke she says "Ahhhh, That's not straight!". Based on your X-rays, it is evident that you do not have a congenital problem. You have a condition called "Adult Onset Idiopathic Scoliosis". I believe your spine is reacting to the abnormal postures over the past few years and it caught up with you on your growth spurs. Your body has changed due to the pressures loads as result of poor postural habits and demands. This is noted in many ergonomic evaluations on adults. In past children were more physically active and did not spend their time looking down other than homework for few hours a day. That has changed dramatically with phones, tablets, laptops now your body is reacting to these changes.

For every 1" that your head is off its center, there is between 10-15 lb. of pressure loading on your spine. kepangi\&white

\section{Radiology Report}

\section{X-Ray Impression}

Reverse C/S curve of-12'/45'

Early onset of posterior bone spur at C7

Scoliosis is simple from T8-L5

Right Concave Scoliosis

Pelvis rotation (Compensatory change due to Right Rotation of Vertebral bodies from L3- T9 creates a Complex Scoliosis

\section{DDX}

Reverse $\mathrm{C} / \mathrm{S}$ curve $=$ Alordosis

Compensatory Rotary Scoliosis (Thoraco-Lumbar spine)

Non-Congenital Scoliosis

\section{Discussion}

\section{Range of Scoliosis}

phase I- 5'-2'degrees:

Conservative method.

Care: Physical Rehabilitation \& Chiropractic Alignment. Duration of care 3-6 months, full spine X-ray every 3-6 months. 


\section{Phase II 25'-45' degrees}

Milwaukee/ Other custom made brace and Surgical Candidate.

Care: Aggressive Physical Rehabilitation \& Chiropractic Alignment. Duration of care 6-24 months full spine X-ray every 3-6 months.

phase III $>45^{\prime}$ degrees:

Care: Surgery

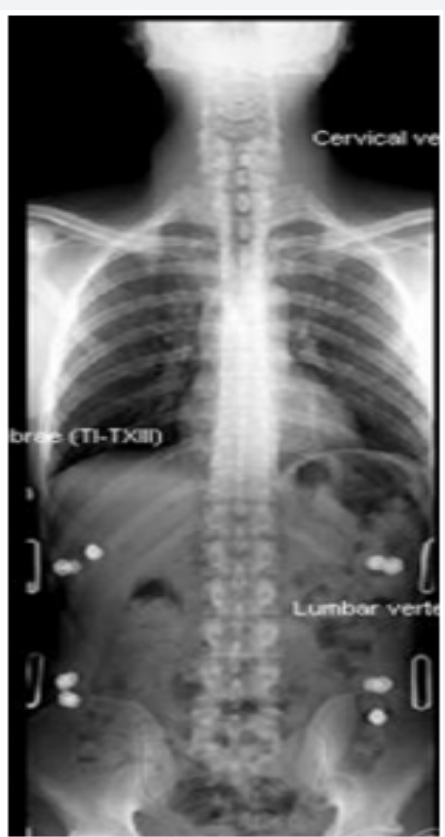

Figure 2: Normal Spine

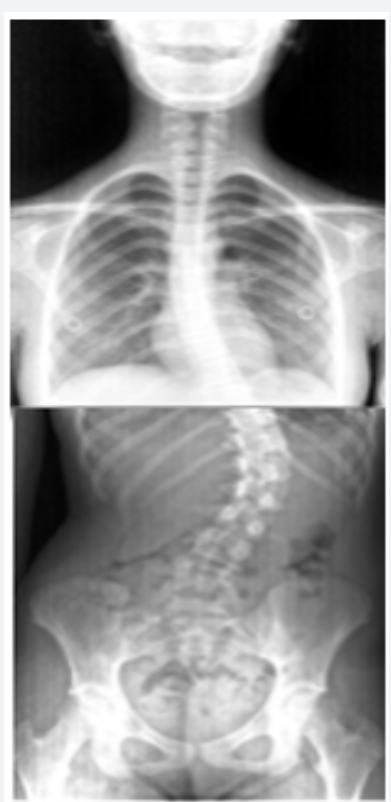

Figure 3: TINA-Female 14yrs.
From that day on we put Tina on strict program of chiropractic, physical therapy, yoga therapy, hard bracing and 9 months later $\$ 30,000.00+$ in out of pocket expense we were able to make some changes to her spine. Tina has to wear a customized brace for many years on daily basis. As a doctor we look at anatomical changes and fail to share with parents the psychological ramifications. A growing child needs to develop his/her personality in society, matters such as confidence, ambition, social interaction are building blocks of a child's emotional IQ. If a child feels he/she is different, has an imperfection, or has to hide a secret, to avoid being ridiculed or bullied. That child's future is at risk (Figures 2-5).
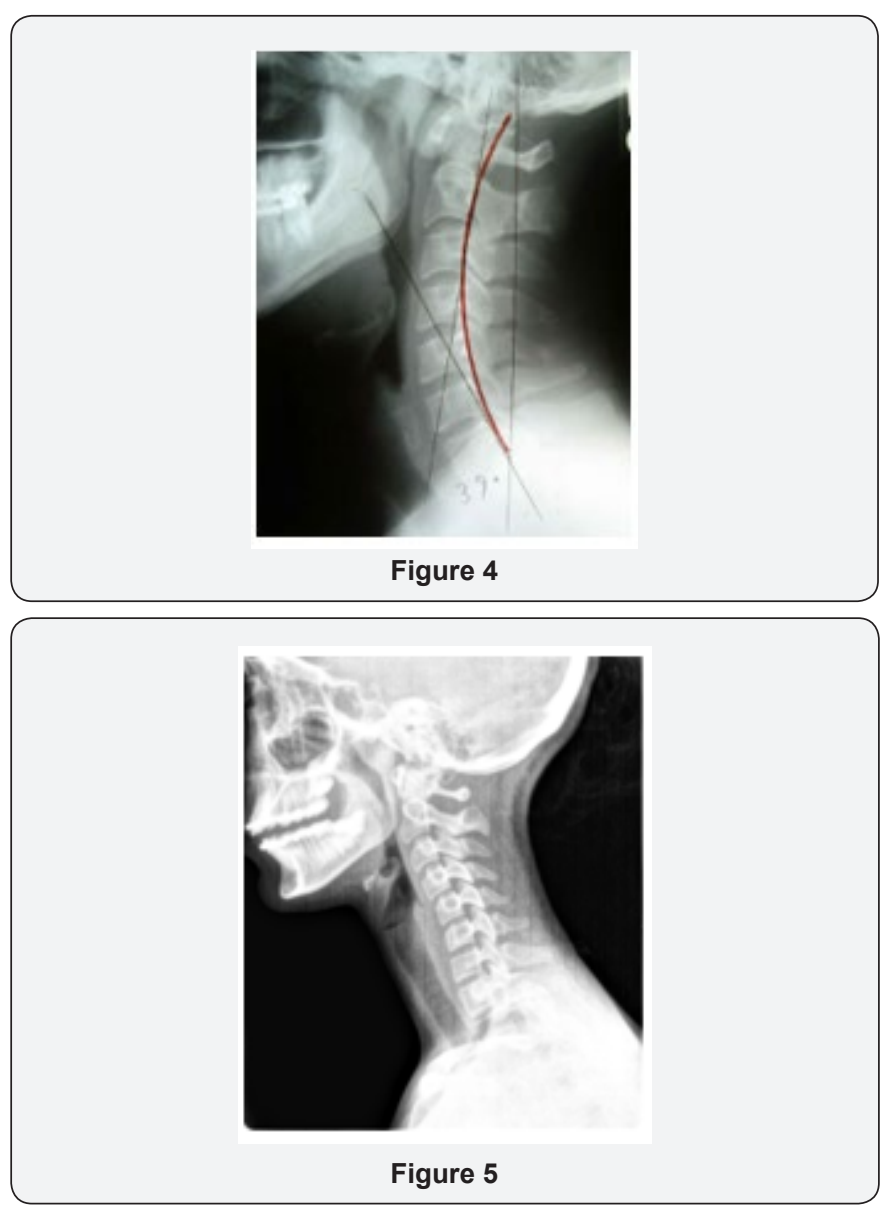

As parents it's important to check your children posture. To raise our future presidents, senators, world leaders not insecure, introverts, make wrong decision as result of poor self image. A simple posture analysis and prevention will change your child's future, Just Maybe! see posture score at www. BAX-U.com

\section{Conclusion}

I share this story, as a godmother, doctor and advocate for better posture better health. My effort is to help adults have better work ergonomic, but prevention starts from home. Find out what your posture Risk Score is and how together we can 
Stand taller, Feel Better and Look Amazing. This personal story is to impress upon you the importance of educating today's parents for healthier children. Together we can make a difference in more ways than you can imagine. I speak out because "I Care". Join our team to educate, empower and promote better health thru early detection and prevention.

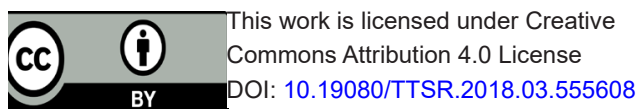

\section{Your next submission with Juniper Publishers will reach you the below assets}

- Quality Editorial service

- Swift Peer Review

- Reprints availability

- E-prints Service

- Manuscript Podcast for convenient understanding

- Global attainment for your research

- Manuscript accessibility in different formats ( Pdf, E-pub, Full Text, Audio)

- Unceasing customer service

Track the below URL for one-step submission https://juniperpublishers.com/online-submission.php 